\title{
ASSEMBLAGE OF NECTARIVOROUS BIRDS AND THEIR FLORAL RESOURCES IN AN ELFIN FOREST OF THE CENTRAL ANDES OF PERU
}

\author{
ENSAMBLE DE AVES NECTARÍVORAS Y SUS RECURSOS FLORALES EN UN \\ BOSQUE ACHAPARRADO DE LOS ANDES CENTRALES PERUANOS
}

\author{
Oscar Gonzalez ${ }^{1}$, Camilo Díaz ${ }^{2}$ and Bernie Britto ${ }^{3}$
}

\begin{abstract}
Nectarivorous birds (hummingbirds, flowerpiercers, and conebills) and their floral resources in an elfin forest of the central Andes of Peru (Unchog, Carpish Mountains) are described. This forest is well-known for its concentration of endemic species, mainly birds. We recorded the nectarivorous birds, vascular plants and the interactions among them between 2011-2014. The birds were recorded by direct observations and mist nets. Plants were evaluated with Gentry plots and occasional collection. A total of 26 nectarivorous bird species have been reported in this forest, however from our observations we detected from this assemblage 17 bird species that feed in plants' nectar. A total of 27 plant species were visited by the birds. The nectarivorous birds were hummingbirds (Trochilidae, 12 species), flowerpiercers (Thraupidae, 4 species) and a conebill (Thraupidae: 1 specie). The plants were from 16 families and 14 orders. One species of hummingbird, Metallura theresiae, is endemic to Peru. On plants, Greigia macbrideana, Puya pseudoeryngioides, Centropogon isabellinus, Miconia alpina and Brachyotum lutescens are endemic to Peru. We comment on the species reported in previous expeditions and in the current checklists. Since this forest is important for its large number of endemic species, we comment on its current threats and the importance of accounting for ecological interactions to conserve montane forests.
\end{abstract}

Key words: montane forests, flowerpiercers, hummingbirds, ecological interactions, Huánuco.

\section{Resumen}

Se describen las aves nectarívoras (colibríes, pinchaflores y picoconos) y sus recursos florales en un bosque achaparrado de los Andes centrales peruanos (Unchog, Cordillera Carpish). Este bosque es bien conocido por su concentración de especies endémicas, principalmente aves. Registramos a las aves nectarívoras, plantas vasculares y sus interacciones entre el 2011 al 2014. Las aves fueron registradas por observaciones directas y redes de neblina. Las plantas fueron evaluadas con parcelas de Gentry y colecta ocasional. Un total de 26 especies nectarívoras han sido reportadas en este bosque, sin embargo, en nuestras observaciones detectamos 17 especies de aves que se alimentan del néctar de las plantas. Un total de 27 especies de plantas fueron visitadas por las aves. Las aves nectarívoras fueron colibríes (Trochilidae, 12 especies), pinchaflores (Thraupidae, 4 especies) y un picocono (Thraupidae: 1 especie). Las plantas fueron de 16 familias y 14 órdenes. Una especie de colibrí, Metallura theresiae, es endémica del Perú. Sobre plantas, Greigia macbrideana, Puya pseudoeryngioides, Centropogon isabellinus, Miconia alpina y Brachyotum lutescens son endémicas del Perú. Comentamos sobre las especies reportadas en expediciones previas y en listas actuales. Puesto que este bosque es importante por su gran número de especies endémicas, comentamos acerca de las amenazas actuales y en la importancia de considerar las interacciones ecológicas para la conservación de los bosques montanos.

Palabras clave: bosques montanos, colibríes, Huánuco, interacciones ecológicas, pinchaflores.

\section{Introduction}

The "montane forest" is dominated by woody vegetation (trees, lianas and bushes) over $1000 \mathrm{~m}$ elevation where the Amazon forest meets the Andes up to 3200 or $3800 \mathrm{~m}$ (Terborgh, 1985; Stotz et al., 1996). It is possible to find different vegetation zones that have their own flora and physiognomy; the soil and amount of precipitation also vary (Richards, 1996). The elfin forest is at the upper top of the montane forest gradient in the Andes ("Bosques pluviales montanos", sensu León et al., 2006), right before the tree-line (Brack \& Mendiola, 2000). This ecosystem includes a community of trees with small leaves and shrubs usually no more than $10 \mathrm{~m}$ tall, loaded with epiphytes, 
mosses and lichens in a permanent cloud base. They grow in soil with quartzite, sandstones and granites, and are also stunted by fire, drought stress and wind pruning (Terborgh, 1971; Stotz et al., 1996; Ashton, 2003). There are elfin forests in other mountain chains besides the Andes (e.g. Puerto Rico; Nevling, 1971); even though the climatic conditions and physiognomy of plants are similar, the species composition is very different. For a discussion in terminology see Stadtmuller (1987). Prance (1989), quoted by Stotz et al. (1996), mentioned that the plant composition is similar to the upper montane forest, with many of the same plant genera but different species of Ericaceae, Brunelliaceae, Clusiaceae, Compositae, Aquifoliaceae, Melastomataceae, Rhamnaceae, Escalloniaceae and Cunoniaceae. Terborgh (1971) included Orchidaceae as predominant. In the treeline of the Andes, trees of the genus Polylepis (Rosaceae) are expected (Ashton, 2003), but there are areas with few individuals. This may be because of intensified logging after the Spanish conquest in the XVI century (Gareca et al., 2013).

Up to $24 \%$ of all terrestrial biodiversity of the planet is estimated to live in the montane forest of tropical America (Birdlife International \& Conservation International, 2005). In Peru, this forest lies in the domain of an Endemic Bird Area known as the Peruvian high Andes, which is of special conservation concern given its high biological importance and current levels of threat; many bird populations are restricted to small forest patches (Terborgh, 1971; Patterson et al., 1998; Stattersfield et al., 1998). The high diversity of species is a result of the topography and habitat heterogeneity, as occurs in AmotapeHuancabamba zone (Mutke et al., 2014). Stotz et al. (1996) report that the elfin forest of the central Andes harbors 34 bird species that use it as primary habitat, and 15 of them are restricted to this kind of forest. These habitat-restricted species that dwell at the top of the mountains are important for the design of nature reserves (Young, 2007). Fjeldsa et al. (1999) found that endemic birds in the tropical Andes are correlated with a history of stable climate; however Young \& León (2007) mention that the treeline near the top of the Andean mountains is a dynamic ecosystem that may promote speciation and a unique community.

Nectarivorous birds have long been recognized as important components of high elevation forests in tropical America (Wolf et al., 1976; Renjifo et al., 1997; Blake \& Loiselle, 2000). For example, Terborgh (1977) while studying bird diversity along an altitudinal gradient in Vilcabamba in Peru, found that nectarivorous birds (hummingbirds and flowerpiercers) accounted for nearly $50 \%$ of the netted individuals near timberline. While in the high Andes forest of Cuzco, Ramirez et al. (2007) and Lloyd (2008) found nectarivorous to be the most abundant guild of birds. Similarly, in the elfin forest of Yanachaga National Park ( $90 \mathrm{~km}$ south-east of Carpish Mountains),
Gonzalez (2008) found Diglossa and Metallura were the most abundant birds in the community. The importance of nectarivorous birds such as hummingbirds as pollinators is well known (Bawa, 1990; Kessler \& Kromer, 2000). In the high Andean forest of Bolivia, where the weather is humid and cold, birds were the main pollinators, especially for Puya spp. and other bromeliads (Kromer et al., 2006). Hummingbirds are the most abundant family of nectarivorous birds and also with most restricted distribution in the tropical Andes (Herzog \& Kattan, 2011).

Here we describe the community of nectarivorous birds and the plants they visit with observations of bird and plant surveys across 4 years (2011-2014) in the elfin forest of Unchog in the cordillera Carpish of Huánuco, Peru. We focused on nectarivorous birds and their plant resources, comparing the expected assemblage of birdplant interactions of the available literature with our results. The surveys were conducted as part of a dissertation project on bird-flowering plant networks (Gonzalez, 2015). We also discuss the previous records of nectarivorous birds in the area and the ecological significance of the plants in the elfin forest ecosystem.

\section{Materials and Methods \\ Study Area}

The Carpish Mountains represent montane forest in central Peru which is rich in endemic species of plants and animals. The Carpish Mountains are in the Department of Huánuco, accessible from the main highway ("carretera central") connecting the cities of Huánuco and Tingo María. Botanical expeditions in this area have occurred since the 18th century with the Spanish explorers Ruiz and Pavon (Beltran \& Salinas, 2010); later expeditions occurred in the 1930's and 1940's (Weberbauer, 1945; Goodspeed \& Stork, 1955). Ferreyra (1950) described the vegetation and was the first to propose that Carpish be designated a national park, due to its high level of endemic species. As Beltran \& Salinas (2010) explain, a single classification for the vegetation system is not possible, so these botanists and the ornithologists Parker \& O'Neill (1976) differentiated the following vegetation zones: premontane forest $(1600-2300 \mathrm{~m})$, montane forest (2 $300-2800 \mathrm{~m})$, elfin forest $(2800-3600 \mathrm{~m})$ and puna grassland (over $3600 \mathrm{~m}$ ).

The Carpish Mountains was not a protected area at the end of this study. The area has been disturbed by cattle grazing and fire (Franke et al., 2005) and the main central highway allowed human colonization that caused severe deforestation (Dourojeanni et al., 2010). Part of the landscape below $2000 \mathrm{~m}$ was already modified in the 1950's and 1970's (Goodspeed \& Stork, 1955; Tallman, 1974), but original vegetation is still present in higher and inaccessible areas, which function as a natural refuge (Sylvester et al., 2014). There remain important portions of elfin forest at the 
treeline that harbor endemic bird species (Wege \& Long, 1995). An assessment of the montane forest in Peru lists this area as a priority for conservation (CDCUNALM \& TNC, 2006).

There have been ornithological studies in Carpish early in the past century (Zimmer, 1930), besides inventories and a description of mixed species flocks (Vuilleumier, 1970). Carpish has been the object of interest for Louisiana State University through several field expeditions (Tallman, 1974; Parker \& O'Neill, 1976). They discovered new species of endemic birds there (Blake \& Hocking, 1974; Lowery \& Tallman, 1976). Carpish has been a preferred place for birdwatching in Peru (Valqui, 2004) because of the high richness of endemic birds, however tourism has not been frequent due to past problems (years 1980 2000) with security in the area. Terrorist groups and drug-dealers have dominated here (Fjeldsa et al., 2005), something that hinders the visit of birdwatchers and researchers (Puhakka et al., 2011). Despite this social problem, Peruvian researchers have completed inventories of plants (Salinas, 2005) and amphibians (Rodríguez, 2007) in the lower areas.

Unchog (3 $800 \mathrm{~m}, 09^{\circ} 42^{\prime} 32.3^{\prime \prime} \mathrm{S}, 076^{\circ} 09^{\prime} 39.1^{\prime \prime} \mathrm{W}$ ), where we did our surveys, is communal land of the Comunidad Campesina Cochabamba of Huánuco. There were three elfin forest patches with continuous vegetative cover (Unchog, Magma and Simeompampa), with $\sim 8$ ha each and no more than 2 $\mathrm{km}$ apart from each other (Figure 1). The predominant trees are several species of the Weinmannia genus, which is common in the Andes above $2000 \mathrm{~m}$ (Rapp et al., 2012). Between these elfin forest patches, there were native shrubs and pastures.

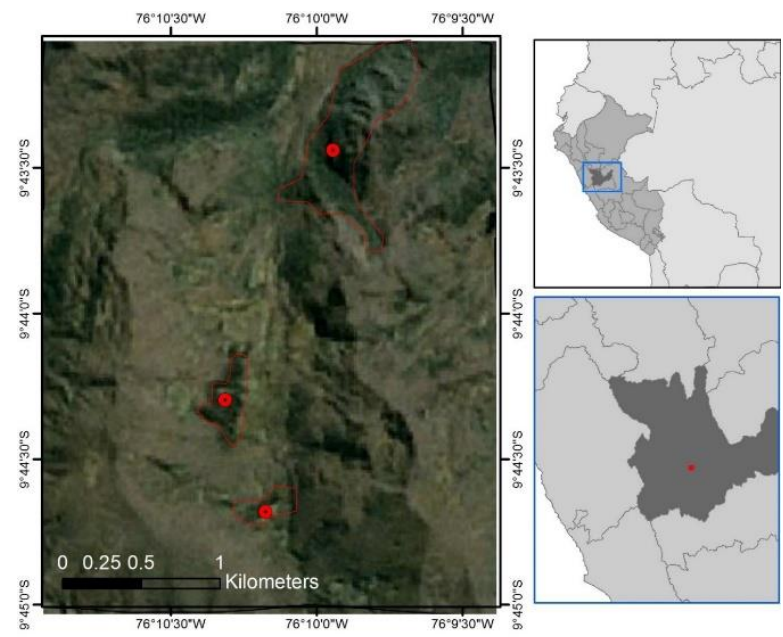

Figure 1. Location of the elfin forest of Unchog in Peru. The forest patches sampled are marked in red.

\section{Data collection}

Unchog forest was visited during different periods from May 2011 to August 2014, over a total of 134 days; 17 days within May-July of 2011, 24 days within
February, July-November of 2012, 41 days in JanuaryJuly, September, November of 2013 and 52 days in January and May-August of 2014. For more details in sampling effort, see Gonzalez \& Loiselle (2016). This forest has a dry and rainy season, and some bird species are more prone to be present or plants blossoming depending on the season. We clumped our observations of both seasons during the entire research time to increase the chance to see all birds and plants of this network. Oscar Gonzalez identified nectarivorous birds (hummingbirds, flowerpiercers and conebills) walking along the forest edges and inside forests mainly in the morning with binoculars. In addition, mist-nets in different areas of the three forests patches were used (2 399 net-hours) and we recorded songs with a Marantz PMD-620 voice recorder and a Sennheiser shotgun microphone. This methodology of bird evaluation followed the protocol of Bibby et al. (2000), mist nets were preferred over point counts as a better method for detection due to the cryptic behavior of small birds in the cloud forest (Martin et al., 2017). We recorded all birds captured in mist nets but for the aim of this study, we are reporting just the nectarivorous. Passerine birds were banded with unique color band codes. Identification follows Schulenberg et al. (2007). The names for the birds were taken from the South American Classification Committee list for Peru (Remsen et al., 2016) and Avibase (Avibase, 2003).

We compared our observations to bird lists from previous expeditions to the area, which were primarily conducted by Louisiana State University, Field Museum of Natural History, American Museum of Natural History and Museo de Historia Natural of the Universidad Nacional Mayor de San Marcos. O. Gonzalez visited the bird collections of these institutions. These expeditions did intense collection of birds in the Unchog area mainly in the summer season (May-August) to survey Carpish mountains. We also used eBird records (eBird, 2015) to document observations of birds in Unchog forest up to July 2014. The eBird data are records of bird species presence taken by professional and amateur birdwatchers (Sullivan et al., 2014), displayed in bird checklists of specific locations evaluated in different ways. We focused the location as "Unchog" in our search.

The survey of flowering plants visited by birds was done by setting up two Gentry plots (Gentry, 1982) which were five transects of $100 \times 2$ m inside the forest patches and occasional collecting by Bernie Britto and Camilo Díaz. This occasional collecting consisted of recording the plants that were not seen inside the plots but were into our study area. Plant identification was done by specimens collected and by photographs. The vouchered plant samples were deposited to the herbarium of the Universidad Peruana Cayetano Heredia and the specimens were compared with others in the herbarium of the Museum of Natural History of the Universidad Nacional Mayor de San Marcos. As 
authorities for plant names we used the works of Mabberley (1987), Brako \& Zarucchi (1993) and The International Plant Names Index (IPNI, n.y.).

For the visualization of the assemblage of nectarivorous birds and their visited plants, we collected the available records on bird-plant visitation of Andean elfin forests from the literature, looking for the species or genera that we recorded in Unchog. Then we ordered the assemblage in a two $\mathrm{x}$ two matrix; by species that have most of the interactions at the top left in a nested structure (Jordano et al., 2009). We called this the theoretical network. Then we ordered our observations on the nectarivorous birds visiting flowers of the plants in the same way, but here we had a qualitative matrix, measured by how many times a bird species visited a plant species. Then we applied the function visweb of the bipartite package in the software program R (Dormann et al., 2008), which is useful to visualize interaction networks in a grid with different colors or tones that represent the strength of the interaction. This quantitative assemblage was called the observed network. We compared the theoretical network with the observed network with parameters for qualitative networks, using the function networklevel in bipartite (Dormann et al., 2008). In order to do this, we converted the quantitative network in a qualitative network for our observed assemblage. Connectance and nestedness were chosen as reliable indicators to compare qualitative networks (Jordano et al. 2009). Connectance measures the proportion of interactions, by dividing the total number of species interactions by the total size of the matrix (Birds x plants). Nestedness measures the order of interactions in the matrix, being zero a random distribution and 100 perfect nestedness; here we used the indicator NODF (Dormann et al., 2008).

\section{Results}

We gathered information on interactions of ten nectarivorous bird taxa with 14 plant taxa from nine sources (Figure 2). The assemblage of birds and plants that we observed interacting by nectar in the elfin forest of Unchog were 44 species (Figure 3). The qualitative data is available in Figshare (Gonzalez, 2016). Connectance in the theoretical network was 0.3, nestedness (NODF) 68.26; while in the observed network, the connectance was 0.385 and nestedness 54.93.

We found a total of 27 plant taxa that were used by birds as nectar sources. The plants belonged to 14 orders, 16 families and 24 genera. None of the plants or bird species were exotic. Two of the genera (Disterigma and Rubus) had multiple species that were identified but we could not confirm whether all of them were visited by the birds (Table 1). The data in eBird (2015) record a total of 26 nectarivorous birds between 2011 and 2014. We evidenced that 17 of them visited flowers of nectar-producing plants. Twelve of these birds belong to the order Apodiformes, family Trochilidae (hummingbirds) and 5 to the order Passeriformes, family Thraupidae (4 flowerpiercers, 1 conebill). The flowerpiercers are considered nectarrobbers (not true pollinators) and the conebill, an occasional nectarivorous bird.

\begin{tabular}{|c|c|c|c|c|c|c|c|c|c|c|}
\hline Brachyotum sp & a & $a, h$ & $f$ & $a, f$ & $a, f$ & $a, f$ & & $g$ & & \\
\hline Bomarea & $a$ & a & $f$ & f & & & $b$ & & $\mathrm{~h}$ & \\
\hline Fuchsia & a & & $f$ & a & $f$ & $a, c, d, f$ & $b$ & & & \\
\hline Disterigma spp. & a & a & & & a & & e & e & & \\
\hline Puya & & $b$ & $f$ & $a, f$ & & a & & & & $b$ \\
\hline Tristerix longibracteatus & a & a & & $a$ & & $a$ & & j & & \\
\hline Desfontainea spinoza & a & a & & a & a & & & & & \\
\hline Gaultheria & a & a & $f$ & & $f$ & & & & & \\
\hline Centropogon & a & & $f$ & $f$ & & & & & & \\
\hline Gaiadendron punctatum & a & a & & & $f$ & & & & & \\
\hline Passiflora & $\mathrm{h}$ & $\mathrm{h}$ & & & & $a, d, f$ & & & & \\
\hline Berberis lutea & & $\mathrm{i}$ & & & & & & & & \\
\hline Tropaeoleum & & & $f$ & & & & & & & \\
\hline Vaccinium floribundum & & & & & & & & & $\mathrm{h}$ & \\
\hline & 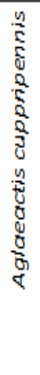 & 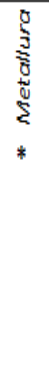 & 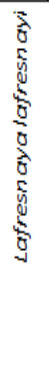 & 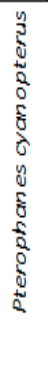 & 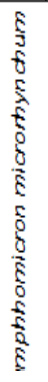 & $\begin{array}{l}0 \\
\frac{5}{5} \\
5 \\
5 \\
0 \\
0 \\
5 \\
5 \\
5 \\
5\end{array}$ & $\begin{array}{l}0 \\
0 \\
0 \\
0 \\
0 \\
0 \\
0 \\
* \\
* \\
*\end{array}$ & $\begin{array}{l}0 \\
0 \\
y \\
0 \\
0 \\
0 \\
0 \\
0\end{array}$ & 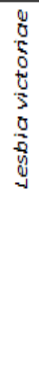 & $\begin{array}{l}y \\
0 \\
0 \\
0 \\
0 \\
5 \\
0 \\
0 \\
0 \\
0 \\
0\end{array}$ \\
\hline
\end{tabular}

$\mathrm{a}=$ Gutierrez \& Rojas (2001), b = Schuchmann (1999), c = Berry (1985), d = Abrahamczyk et al. (2014), e = Navarro et al. (2008), f = Gutierrez-Zamora (2008), g= Stiles et al. (1992), h = Córdova \& Fajardo (2018), i = Hesse (2010).

* The species is tyrianthina in all cases except for M. odomae in Hesse (2010).

** Could be Coeligena torquata or $C$. violifer

Figure 2. Theoretical Bird-flower visitation network in the elfin forest. Plants are in the vertical side and birds in the horizontal side, in a nested order by interaction strength. The letter in each filled square is the reference for that interaction. White squares mean no interaction.

On plants, Greigia macbrideana, Puya pseudoeryngioides, Centropogon isabellinus, Miconia alpina and Brachyotum lutescens are endemic to Peru (León et al., 2006). A bird species of conservation concern is the hummingbird Metallura theresiae, endemic from Peru (Schulenberg et al., 2007). Three of 


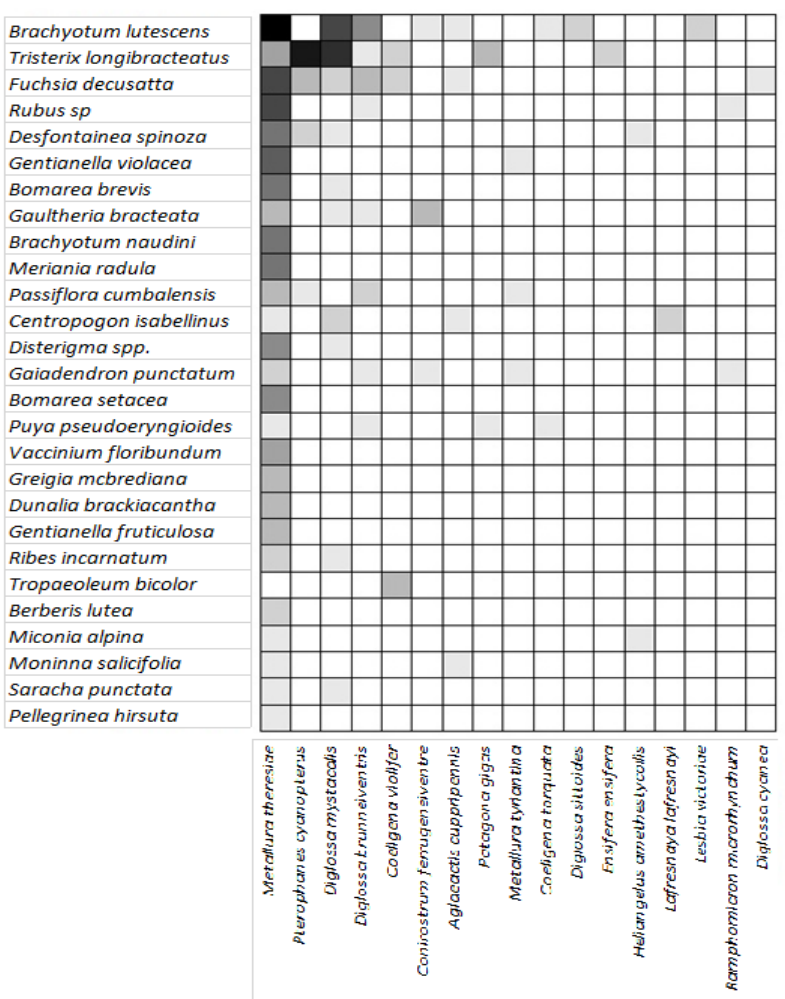

Figure 3. Observed Bird-flower visitation network in the elfin forest. Plants are on the vertical side and birds in the horizontal side, in a nested order by interaction strength. Each filled square represent an interaction, the darker the square, the stronger the interaction is. White squares mean no interaction. The maximum number of interactions was 45 , minimum zero.

the bird species found (Metallura theresiae, Pterophanes cyanopterus and Conirostrum ferrugineiventre) are considered typical of the elfin forest by Parker et al. (1996).

\section{Discussion}

Network properties of the nectarivorous assemblage

The assemblages, or networks of nectarivorous birds and their resources provide an important framework to study ecological principles such as diversity, distribution, adaptation and energy flow (Rojas-Nossa, 2013; Bennett et al., 2014; Abrahamczyk \& Kessler, 2015; Gonzalez \& Loiselle, 2016). The information gathered from nine sources on nectarivorous birds that visited plants in the Andes gave us a limited view of the real interactions in the elfin forest, because there were fewer taxa than in the observed network. The connectance of the observed network was higher, but the nestedness lower. This could indicate that the assemblage of plants and nectarivorous birds could be more fragile than expected because nestedness is considered an indicator of resistance of communities to perturbations (Bascompte et al., 2003). However, we have the limitation that this theoretical network is a compilation of data from different areas, even though from tropical Andean forests, the endemism of plants and animals is high (Stattersfield et al., 1998) and the preferences of birds on specific plants might switch. Then, it is important to analyze in some detail the members of the assemblage.

Nectarivorous Birds

We recorded the nectarivorous bird species that were reported by Tallman (1974) and Parker \& O'Neill (1976), who did intensive search for birds in the Carpish area; but not all of the species in the eBird record (2015) were seen in Unchog forest or interacting with plants (Table 2). The species of this potential network that we did not record in the interactions were Colibri thalassinus, Colibri coruscans, Chalcostigma ruficeps, Chalcostigma stanleyi, Metallura phoebe, Agaleactis castelnaudii, Amazilia chionogaster, Conirostrum cinereum and Conirostrum sitticolor. However, during our field study (2011-2014) almost all the records for eBird (2015) were in the dry season; there were no records in February, April and September.

It is highly likely that the contributing people for the eBird records went outside the limits of the elfin forest to see these species, because the tourists who come to this birding hotspot do not just birdwatch in the elfin forest. They get in the montane scrub of the Huallaga valley that borders with the elfin forest and they can also go beyond this forest to the cloud forest limit; it is possible to see bird species there that do not frequent the core of the elfin forest (Valqui, 2004). The White-tufted Sumbean Agaleactis castelnaudii was recorded in eBird's record of Unchog by three people (eBird, 2015), two of them said that they saw them in the montane scrub outside the elfin forest (F. Schmidt, G. Schoezler, personal communication to $\mathrm{O}$. Gonzalez). A. castelnaudii with White-bellied hummingbird Amazilia chionogaster and Sparkling Violetear Colibri coruscans are usually seen in the neighboring habitat too (O. Gonzalez, personal observation). The altitudinal limit of $A$. chionogaster is $3500 \mathrm{~m}$, and Green violetear Colibri thalassinus is 3 $300 \mathrm{~m}$. These are located below our observation areas. A. chionogaster was seen just once at the beginning of the study and was not seen visiting any flower. $C$. thalassinus is known to make altitudinal migrations in Central America (Levey \& Stiles, 1992). Black Metaltail Metallura phoebe usually does not overlap with other species of Metallura (Schulenberg et al., 2007), but it could be confused with $M$. theresiae which seems black from a distance. The data on eBird can be a good reference to look for distributions (Sullivan et al., 2014), however it is necessary to recheck the data for possible mistakes before using it for comparison in a specific region (Gonzalez \& Wethington, 2014). We registered Purple-backed Thornbill Ramphomicron microrhynchum as well as Parker \& O'Neill (1976); but 
Enero - Julio 2019

this species was not in the eBird's checklist (eBird, 2015) within the temporal and spatial range surveyed. The inclusion of a conebill as a nectarivorous bird might seem odd, but Moynihan (1963) mentioned that the species of this group are partly nectarivorous.

The tree line of Manu National Park, in the southern Peruvian Andes, has a very similar landscape to Unchog. Lloyd et al. (2012) found out a distinctive community of plants and birds, different from puna grasslands and the cloud forest. Bird pollinators that are expected in tree line zones include a dozen hummingbirds such as Great Sapphirewing Pterophanes cyanopterus, Sword-billed Hummingbird Ensifera ensifera and species of the genus Coeligena, Eriocnemis and Heliangelus, the last two restricted to the elfin forest. We did not observe Eriocnemis in this study.

The Coppery Metaltail Metallura theresiae was the most dominant flower visitor in this ecosystem, so it could be the most effective pollinator (Willmer, 2011). In other tree line ecosystems in the central Andes, the small hummingbirds Tyrian Metaltail Metallura tyrianthina and Amethyst-throated Sunangel Heliangelus amethysticollis are dominant (Gonzalez, 2008; Lloyd et al., 2012; Toloza-Moreno et al., 2014) but in Unchog, $M$. theresiae has taken over the tree line and these other hummingbirds stay in lower elevations. The diversification of Metallura hummingbirds was recent (Garcia-Moreno et al., 1999), hummingbirds have their beta-diversity associated with elevation (Weinstein et al., 2014). M. tyrianthina is subordinate (Does not compete, it is not dominant) to M. theresiae and other sister species when it is present at higher elevations (Heindl \& Schuchmann, 1998).

Hummingbirds of the genus Coeligena visits several species of plants in Andean forests, Schuchmann (1999) reported them visiting Bomarea, but we did not observe Coeligena feeding on Bomarea. The other plants reported by Schuchmann were not in our study area. Schuchmann (1999) also did not report Tristerix as food for Pterophanes cyanopterus as we observed. Gutiérrez \& Rojas (2001) in the paramos of Colombia, found that there is a strong dependence of several small billed hummingbirds with Brachyotum. They also found dependence of Pterophanes with Puya; but not with Tristerix which was also present there. Metallura odomae, sister taxa of Metallura theresiae in high elevation montane forest in the north of Peru feeds mainly in Brachyotum and in Berberis (Hesse, 2010). Small-billed hummingbirds rely on Brachyotum, its importance in the network is explained in Gonzalez \& Loiselle (2016). Schuchmann (1999) mentions that the Shining Sunbeam Aglaeactis cupripennis does local migrations, Heliangelus prefers shrubs in the ecotone between paramo and forest and Coeligena forages in the forest itself or forest edges.

The Moustached flowerpiercer Diglossa mystacalis has a large range that is not limited to the elfin forest
(Parker \& O’Neill 1976); Black-throated Flowerpiercer Diglossa brunneiventris is common in disturbed areas and non-forested habitat (Becker et al., 2008; Vaicenbacher et al., 2014). Masked Flowerpiercer Diglossa cyanea travels with mixed species flocks in cloud forests (Guevara et al., 2011; Arbelaez-Cortes \& Marin-Gomez, 2012) and was uncommon.

Flowering plants visited by birds

The ornithophilus plants expected in the elfin forest according to Schuchman (1999) could be woody, vines and shrubs. Those are members of the genus Bomarea, Fuchsia, Lobelia, Passiflora, Brachyotum, Befaria or Datura. We did not find visitors for Lobelia, Befaria or Datura.

As Stiles (1985) described, in high elevation ecosystems like this elfin forest, the birds pollinate mainly shrubs. The Melastomataceae Brachyotum, Meriania and Miconia were cataloged as hummingbird-pollinated by Varassin et al. (2008). The shrub Brachyotum spp. is an important source of nectar of several nectarivorous species in this region; first descriptions on the flowers of this genus noted that hummingbirds pollinate it (Renner, 1989a). However, Stiles et al. (1992) suggested that these plants are adapted to pollination by the Diglossa flowerpiercers. The plant more connected was Brachyotum lutescens which is an endemic species of Peru only found in this region and maybe in critical situation (León, 2006). As for the shrub Hypericum, common here and in the northern Andes paramo (Caceres et al., 2014), the shrub Brachyotum may be a foundational species; they are the first in colonizing a non-woody area and start forest regeneration (Guenter et al., 2009). Furthermore, Brachyotum facilitates movement among forest patches as nectarivorous birds that move between patches may forage on Brachyotum which is common in the nonforested matrix. Similar to Gutiérrez \& Rojas (2001), who studied a tree line zone between montane forest and paramo, Brachyotum (B. lutescens and B. naudini) is most visited by hummingbirds and then other plants identified in this study: Fuchsia, Passiflora and Tristerix.

Ollerton et al. (2009) identified the plants that have birds as pollinators in the elfin forest of Urubamba (Cuzco). Plants that have a common genus in Unchog forest are: Bomarea, Fuchsia, Gaultheria, Passiflora, Puya, and Rubus. Wolf et. al. (1976) reported that Centropogon and Fuchsia are common plants used by hummingbirds in the high altitude forest of Central America. Cronk \& Ojeda (2008) and Willmer (2011) identified Fuchsia and Passiflora as typical birdpollinated flowers. Botanists such as Weberling (1989) and Gentry (1993) recognize that Fuchsia plants are adapted for the visitation by hummingbirds. Gentry (1993) also confirmed that Brachyotum and Tristerix are characteristic for hummingbird pollination. In New Zealand, Tristerix is known to suffer the effect of pollination limitation in the seed set (Montgomery et 
al., 2001), even though is self-compatible. However, it has populations that are gynodioecious (hermaphrodite and female flowers) so that could be an evolutionary advantage in case there would not be pollinators (Arroyo \& Raven, 1975; Atsatt \& Rundel, 1982; Robertson et al., 1999). In one hermaphroditic species of Fuchsia, its nectar production is assumed related to the evolution of the pollination traits of the flower (Atsatt \& Rundel, 1982). The presence of Ensifera ensifera in the montane forest limit with the paramo in Colombia is associated with the presence of blossoming peaks of Fuchsia and Passiflora (Gutiérrez \& Rojas, 2001). However, specialization in pollination networks can be misleading (Schemske, 1983). In Unchog Ensifera, was seen occasionally and not visiting Passiflora but Tristerix. Furthermore, Metallura theresiae visited Passiflora flowers illegitimately (Gonzalez \& Loiselle, 2016). Benevides et al. (2013) stated that Passiflora is a very important resource for several pollinators, but this plant was scarce in the elfin forest and did not receive many visitors.

It is known that Puya is a very important source for hummingbirds in the high Andes (Woods \& Ramsay, 2001; Salinas et al., 2007; Hornung-Leoni et al., 2013). Schuchmann (1999) states that Patagona gigas is highly dependent on Puya. Besides this hummingbird species, we observed Coeligena torquata, Metallura theresiae and Diglossa brunneiventris visiting Puya, but the dependence on them was weak.

The blackberry Rubus had more than one species in the network but the shape of the flowers was very similar in all species. Berberis and Tropaeolum are genera that are present also in the Chilean Andes, but the weather here is temperate and they are pollinated by insects (Arroyo et al., 1982). The shrub Dunalia spinosa, related to D. brakiacantha in a premontane habitat also in the Chilean Andes, has flowers rich in nectar and is visited by different birds (Torres-Mura \& Hertel, 2006). In a study involving Disterigma in Colombia, small-billed hummingbirds were the most common visitors; with Coeligena and a Diglossa that robbed its nectar as seldom visitors (Navarro et al., 2008). In the sampling we detected Cavendishia bracteata, Pernettya postratta and Fuchsia apetala; the first two flowers were visited by hummingbirds in Colombia (Gutierrez-Zamora, 2008). F. apetala has large and orange flowers, but we did not see any bird visitor to this species. Plants with small flowers such as Pernettya postrata and Gualtheria spp. could be able to self-pollinate (Luteyn, 2002) and did not have a strong dependence with birds. Epiphytes, which are known to be important as nectar resource in montane forests (Kromer et al., 2006) were almost absent here because at high elevations close to the treeline, the abundance of epiphytes drops (Zotz et al., 2014).
Factors that affect the assemblage

It is important to consider the bird composition of this assemblage might be affected by local movements or migrations, nectarivorous birds have been recorded to have local migrations in another montane forest such as in Manu (Merkord, 2010) or Costa Rica (Levey \& Stiles, 1992; Boyle et al., 2011). On local movements of the birds in Unchog, it was observed that only one Diglossa mystacalis of 69 banded flowerpiercers ( $D$. mystacalis and D. brunneiventris) switched between forest patches in 8 months. We do not have information on movements of the hummingbirds here. It is known that hummingbirds fly long distances following floral resources (Levey \& Stiles, 1992; Hobson et al., 2003; Gutierrez et al., 2004) and usually move between fragments of montane forest and high montane scrub habitats at high elevations (Toloza-Moreno et al., 2014). Even Metallura theresiae is observed all year round and nesting at different times of the year in the elfin forest (O. Gonzalez, personal observation) we cannot discard the possibility that this hummingbird moves to lower elevations. Hobson et al. (2003) proved with isotopes that hummingbirds move along an elevational gradient in a montane forest, among them Metallura baroni, an endemic. However, Metallura theresiae is at the core of the network observed here (Gonzalez \& Loiselle, 2016) and appears to be constant throughout time and space (eBird, 2015).

About other vertebrates that are nectarivorous, bats are a possibility in our study area. Even though we did not observe bats visiting flowers, it is probable that nectarivorous bats of genus Anoura, observed in the upper montane forest of Yanachaga-Chemillen National Park (90 km southeast) reach the elevation of the elfin forest (Vivar, 2006); and pollinate Macrocarpaea flowers (Renner, 1989b); this tree has populations limiting the elfin forest. There are records in the Kosnipata valley in Cusco (1 $600 \mathrm{~m}$. elevation) of Rubus pollen transported by bats (Maguina et al., 2012) and of Passiflora pollen in a montane forest in Ecuador (Muchhala \& Jarrin-V, 2002). Insects visited some plants that birds also visit; in the dry season of 2014 a total of $29 \%$ of the flower visitors of Gentianella violacea were insects (O. Gonzalez, unpublished data).

Unchog forest is a place of high endemism of the tropical Andes, shown by this assemblage of nectarivorous birds and their resources, as well as several other birds and plants. This endemism in elfin forests leads to its importance for conservation efforts (Herzog \& Kattan, 2011; Tejedor-Garavito et al., 2014). Unfortunately, the elfin forest is highly fragmented; and habitat loss by deforestation due to logging, livestock grazing or clearance for agriculture could hasten loss of pollinators and pollinator services. Detailed research is needed on the individual responses of plants to deforestation (Renner, 1998). The conservation of the tree line ecosystems, where there 
are remnants of elfin forests and enclosed watersheds are the resources for nectarivorous birds and also for several endemics, should be a priority for conservation (Ramirez-Villegas et al., 2014).

\section{Acknowledgments}

We thank Juan Diego Shoobridge for his help in plant identification, Carolina Tovar for making the maps and Bette Loiselle for reviewing drafts of this paper. O. Gonzalez thanks FINCyT in Peru for funding his Ph.D. studies. Visit to the herbarium of the Universidad Nacional Mayor de San Marcos was done with the permit No. 60-2012-USM. The field research was done with permits No. 151-2014-MINAGRIDGFFS-DGEFFS and 182-2012-AG- DGFFSDGEFFS of the Peruvian government. This work was supported by the Premio Nacional para la Investigacion Ambiental of the Ministerio del Ambiente of Peru, Optics for the Tropics, Royal Society for Bird Protection, Idea Wild and University of Florida's Tropical Conservation and Development Program field research fund. Funds to visit the museums in the US came from a Day Star Science Advocacy Research Grant.

\section{Cited literature}

Abrahamczyk S. \& Kessler M. 2015. Morphological and behavioural adaptations to feed on nectar: how feeding ecology determines the diversity and composition of hummingbird assemblages. Journal of Ornithology, 156(2): 333-347. DOI: $10.1007 / \mathrm{s} 10336-014-1146-5$.

Abrahamczyk S., Souto-Vilaros D. \& Renner S.S. 2014. Escape from extreme specialization: passionflowers, bats and the sword-billed hummingbird. Proceedings of the Royal Society B-Biological Sciences, 281. DOI: 10.1098/rspb.2014.0888.

Arbelaez-Cortes E. \& Marin-Gomez O.H. 2012. The composition of mixed-species bird flocks in Alto Quindio, Colombia. Wilson Journal of Ornithology, 124: 572-580. DOI: http://dx.doi.org/10.1676/11-132.1.

Arroyo M.T.K. \& Raven P.H. 1975. Evolution of subdioecy in morphologically gynodioecious species of Fuchsia sect encliandra (Onagraceae). Evolution, 29: 500-511. DOI: $10.2307 / 2407262$.

Arroyo M.T.K., Primack R. \& Armesto J. 1982. Community Studies in Pollination Ecology in the High Temperate Andes of Central Chile. 1. Pollination Mechanisms and Altitudinal Variation. American Journal of Botany, 69: 82-97.

http://link.springer.com/article/10.1007\%2FBF0098330 5.

Ashton P.S. 2003. Floristic zonation of tree communities on wet tropical mountains revisited. Perspectives in Plant Ecology Evolution and Systematics, 6: 87-104. DOI: 10.1078/1433-8319-00044.

Atsatt P.R. \& Rundel P.W. 1982. Pollinator maintenance vs fruit production - partitioned reproductive effort in subdioecious Fuchsia lycioides. Annals of the Missouri Botanical Garden, 69: 199-208. DOI: 10.2307/2398790.

Avibase. 2003. Avibase - The World Bird Database. URI: https://avibase.bsc-eoc.org/.
Bascompte J., Jordano P., Melián C.J. \& Olesen J.M. 2003. The nested assembly of plant-animal mutualistic networks. Proceedings Natural Academy of Sciences USA, 100: 9383-9387.

Bawa K.S. 1990. Plant-pollinator interactions in tropical rain forests. Annual Review of Ecology and Systematics, 21: 399-422. DOI: 10.1146/annurev.es.21.110190.002151.

Becker C.D., Loughin T.M. \& Santander T. 2008. Identifying forest-obligate birds in tropical moist cloud forest of Andean Ecuador. Journal of Field Ornithology, 79: 229244. DOI: 10.1111/j.1557-9263.2008.00184.x.

Beltran H. \& Salinas I. 2010. The vascular flora and vegetation of the Carpish Humid Montane Forests (Huánuco - Peru). Arnaldoa 17(1): 107-130.

Benevides C.R., Evans D.M. \& Gaglianone M.C. 2013. Comparing the Structure and Robustness of Passifloraceae - Floral Visitor and True Pollinator Networks in a Lowland Atlantic Forest. Sociobiology, 60(3): 295-305. http://periodicos.uefs.br/index.php/sociobiology/article/v iew/188.

Bennett J.M., Clarke R.H., Thomson J.R. \& Mac Nally R. 2014. Variation in abundance of nectarivorous birds: does a competitive despot interfere with flower tracking? Journal of Animal Ecology, 83(6): 1531-1541. DOI: 10.1111/1365-2656.12245.

Berry P. 1985. The systematics of the apetalous Fuchsias of South-America, Fuchsia sect hemsleyella (Onagraceae). Annals of the Missouri Botanical Garden, 72: 213-251. DOI: $10.2307 / 2399177$.

Bibby C., Burguess E., Hill D. \& Mustoe S. 2000. Bird Census Techniques. Second Edition. Academic Press. United Kingdom.

Birdlife International \& Conservation International. 2005. Áreas Importantes para la Conservación de las Aves en los Andes Tropicales: sitios prioritarios para la conservación de la biodiversidad. Quito: BirdLife International. (BirdLife Conservation Series $N^{\circ} 14$ ).

Blake E.R. \& Hocking P. 1974. Two new species of tanager from Peru. The Wilson Bulletin, 86(4): 321-324. https://sora.unm.edu/node/129111.

Blake J.G. \& Loiselle B.A. 2000. Diversity of birds along an elevational gradient in the Cordillera Central, Costa Rica. Auk, 117(3): 663-686. https://sora.unm.edu/sites/default/files/journals/auk/v117 n03/p00663-p00686.pdf.

Boyle W.A., Conway C.J. \& Bronstein J.L. 2011. Why do some, but not all, tropical birds migrate? A comparative study of diet breadth and fruit preference. Evolutionary Ecology, 25(1): 219-236. http://link.springer.com/article/10.1007\%2Fs10682-0109403-4.

Brack A. \& Mendiola C. 2000. Ecologia del Peru. Editorial Bruño. Lima. Peru.

Brako L. \& Zarucchi J. 1993. Catálogo de las Angiospermas y Gimnospermas del Perú. Monographs in Systematic Botany from the Missouri Botanical Garden. 45: 763-867.

Caceres Y., Lambda L.D. \& Rada F. 2014. Shrubs as foundation species in a high tropical alpine ecosystem: a multi-scale analysis of plant spatial interactions. Plant Ecology and Diversity, 8(2): 147-161. DOI: dx.doi.org/10.1080/17550874.2014.960173. 
CDC-UNALM (Centro de Datos para la Conservación Universidad Nacional Agraria La Molina) \& TNC (The Nature Conservancy). 2006. Planificación para la Conservación Ecoregional de las Yungas Peruanas: Conservando la Diversidad Natural de la Selva Alta del Perú. Informe Final. Lima, Perú.

Córdova Alvarez M.C. \& Fajardo Alvarado P.C. 2018. Efectos de la disponibilidad de Oreocallis grandiflora (Lam.) R. Br. (Proteaceae) en las redes de interacción de polinización de colibríes en matorrales montano andinos al sur del Ecuador. Tesis para título de Biólogo. Universidad del Azuay. Ecuador.

Cronk Q. \& Ojeda I. 2008. Bird-pollinated flowers in an evolutionary and molecular context. Journal of Experimental Botany, 59(4): 715-727. DOI: 10.1093/jxb/ern009.

Dormann C.F., Gruber B \& Fründ J. 2008. Introducing the bipartite package: Analysing Ecological Networks. R News, 8(2): 8-11.

Dourojeanni M., Barandarian A. \& Dourojeanni D. 2010. Amazonía peruana en 2021. Explotación de recursos naturales e infraestructuras: ¿Qué está pasando? ¿Qué es lo que significan para el futuro? Bois et forêts des tropiques, 305(3):

$77-82$ http://bft.cirad.fr/cd/BFT_305_77-82.pdf.

eBird. 2015. eBird: An online database of bird distribution and abundance. eBird, Ithaca, New York. http://www.ebird.org.

Ferreyra R. 1950. Informe botánico de la exploración científica al valle del Huallaga. In: Organismo Coordinador de la Hilea Amazónica Peruana. Informe sobre el Huallaga. 177-217. Ministerio de Relaciones Exteriores. Lima.

Fjeldsa J., Alvarez M.D., Lazcano J.M. \& Leon B. 2005. Illicit crops and armed conflict as constraints on biodiversity conservation in the Andes region. Ambio, 34(3): 205-211. DOI: http://dx.doi.org/10.1579/00447447-34.3.205.

Fjeldsa J., Lambin E. \& Mertens B. 1999. Correlation between endemism and local ecoclimatic stability documented by comparing Andean bird distributions and remotely sensed land surface data. Ecography, 22(1): 63 78. DOI: 10.1111/j.1600-0587.1999.tb00455.x.

Franke I., Mattos J., Salinas L., Mendoza C. \& Zambrano S. 2005. Areas importantes para la conservacion de las aves en Perú. In: Boyla K. \& Estrada A. (eds.). Areas Importantes Para la Conservación de las Aves en los Andes Tropicales. 471-619. Birdlife International. Quito, Ecuador.

Garcia-Moreno J., Arctander P. \& Fjeldsa J. 1999. Strong diversification at the treeline among Metallura hummingbirds. Auk, 116(3): 702-711. https://sora.unm.edu/sites/default/files/journals/auk/v116 n03/p0702-p0711.pdf.

Gareca E.E., Breyne P., Vandepitte K., Cahill J.R.A., Fernandez M. \& Honnay O. 2013. Genetic diversity of Andean Polylepis (Rosaceae) woodlands and inferences regarding their fragmentation history. Botanical Journal of the Linnean Society, 172(4): 544-554. DOI: 10.1111/boj.12055.
Gentry A.H. 1982. Patterns of neotropical plant diversity. In: Hecht M.K., Wallace B., Prance G.T. (eds) Evolutionary Biology. Springer. Boston, MA. http://link.springer.com/chapter/10.1007\%2F978-14615-6968-8_1.

Gentry A.H. 1993. A Field Guide to Woody Plants of Northwest South America (Colombia, Ecuador, Peru). Conservation International, Washington, DC.

Gonzalez O. \& Loiselle B. 2016. Species interactions in an Andean bird-flowering plant network: phenology is more important than abundance or morphology. PeerJ, 4: e2789. DOI: https://doi.org/10.7717/peerj.2789.

Gonzalez O. \& Wethington S. 2014. Observaciones de los colibries y sus recursos de néctar en el bosque nublado de la Carretera Manu, Perú. The Biologist (Lima), 12(1): 109-115.

URI: https://dialnet.unirioja.es/servlet/articulo? codigo $=47557$ $\underline{04}$.

Gonzalez O. 2008. Aves de la Selva Central Peruana: Levantamiento de información ornitológica del Parque Nacional Yanachaga-Chemillen. Technical Report submitted to the Office of Natural Protected Areas, INRENA. PROFONANPE. Lima, Peru. DOI: 10.13140/RG.2.1.3137.3686.

Gonzalez O. 2015. Bird-flowering plant networks in Andean montane forests. Ph.D. Dissertation. University of Florida.

Gonzalez O. 2016. Nectarivorous Bird Plant Visitation Networks in the Andes. Figshare. https://figshare.com/s/3903e803bedc61aeee81.

Goodspeed T.H. \& Stork H.E. 1955. The University of California Botanical Garden expeditions to the Andes (1935-1952): With observations on the phytogeography of Peru. Univ.Calif. Publ. Bot., 28(3): 79-142.

Guenter S., Gonzalez P., Alvarez G., Aguirre N., Palomeque X., Haubrich F. \& Weber M. 2009. Determinants for successful reforestation of abandoned pastures in the Andes: Soil conditions and vegetation cover. Forest Ecology and Management, 258(2): 81-91. DOI: 10.1016/j.foreco.2009.03.042.

Guevara E.A., Valarezo J.C., Onofa A. \& Cupueran F. 2011. Mixed-species flock composition in a northwestern Ecuadorian cloud forest. Ornitologia Neotropical, 22(3): 379-386. https://sora.unm.edu/node/133246.

Gutiérrez A. \& Rojas S. 2001. Dinámica anual de la interacción colibrí-flor en ecosistemas altoandinos del volcán Galeras, sur de Colombia. Tesis de grado, Universidad Nacional de Colombia, Bogotá, Colombia.

Gutierrez A., Rojas-Nossa S.V. \& Stiles F.G. 2004. Dinámica anual de la interacción colibrí-flor en ecosistemas altoandinos. Ornitologia Neotropical, 15 (Suppl.): 205213.

https://sora.unm.edu/sites/default/files/journals/on/v015s /p0205-p0214.pdf.

Gutierrez-Zamora A. 2008. Ecological interactions and structure of a high Andean community of hummingbirds and flowers in the eastern Andes of Colombia. Ornitologia Colombiana, 7: 17-42. http://asociacioncolombianadeornitologia.org/wpcontent/uploads/revista/oc7/gutierrez.pdf.

Heindl M. \& Schuchmann K.L. 1998. Biogeography, geographical variation and taxonomy of the Andean hummingbird genus Metallura GOULD, 1847. Journal of Ornithology, 139: 425-473. 
Herzog S. \& Kattan G. 2011. Patterns of Diversity and Endemism in the Birds of the Tropical Andes. In: Herzog S.K., Martínez R., Jørgensen P.M. \& Tiessen H. (eds.). Climate Change and Biodiversity in the Tropical Andes. 245-259. MacArthur Foundation, Interamerican Institute for Global Change Research and Scope. New York. USA.

Hesse M.V. 2010. Las aves del Santuario Nacional Tabaconas Namballe. In: Mena Alvarez J.L. \& Valdivia G. (eds.) Conociendo el Santuario Nacional Tabaconas Namballe. 43-50. WWF, Lima.

Hobson K.A., Wassenaar L.I., Mila B., Lovette I., Dingle C. \& Smith T.B. 2003. Stable isotopes as indicators of altitudinal distributions and movements in an Ecuadorean hummingbird community. Oecologia, 136(2): 302-308. http://link.springer.com/article/10.1007\%2Fs00442-0031271-y.

Hornung-Leoni C.T., Gonzalez-Gomez P.L. \& Troncoso A.J. 2013. Morphology, nectar characteristics and avian pollinators in five Andean Puya species (Bromeliaceae). Acta Oecologica (International Journal of Ecology), 51: 54-61. DOI:10.1016/j.actao.2013.05.010.

IPNI. [n.y.]. The International Plant Names Index. Kew Royal Botanic Gardens. Kew, UK. URI: https://www.ipni.org/.

Jordano P., Vázquez D. \& Bascompte J. 2009. Redes complejas de interacciones mutualistas planta-animal. In: Medel R., Aizen M. \& Zamora R. (eds.). Ecología y evolución de las interacciones planta-animal: conceptos y aplicaciones. 17-41. Editorial Universitaria. Santiago de Chile. Chile.

Kessler M. \& Kromer T. 2000. Patterns and ecological correlates of pollination modes among bromeliad communities of Andean forests in Bolivia. Plant Biology, 2(6): 659-669. DOI: $10.1055 / \mathrm{s}-2000-16642$.

Kromer T., Kessler M. \& Herzog S.K. 2006. Distribution and flowering ecology of bromeliads along two climatically contrasting elevational transects in the Bolivian Andes. Biotropica, 38: 183-195. DOI: 10.1111/j.17447429.2006.00124.x.

León B. 2006. Melastomataceas endémicas del Perú. Revista Peruana de Biología, Número especial (El Libro rojo de las plantas endémicas del Perú), 13(2): 428S-452S. DOI: https://doi.org/10.15381/rpb.v13i2.1879http://www.sci elo.org.pe/scielo.php?pid=S172799332006000200075\&script=sci_arttext.

León B., Sagastegui A, Sanchez I. \& Zapata M. 2006. Bromeliaceae endémicas del Perú. Revista Peruana de Biología, Número especial (El Libro rojo de las plantas endémicas del Perú), 13(2): 708S-737S. DOI: https://doi.org/10.15381/rpb.v13i2.1941 .

Levey D. \& Stiles F. 1992. Evolutionary Precursors of LongDistance Migration - Resource Availability and Movement Patterns in Neotropical Landbirds. The American Naturalist, 140(3): 447-476. http://www.jstor.org/stable/2462776.

Lloyd H. 2008. Abundance and patterns of rarity of Polylepis birds in the Cordillera Vilcanota, southern Perú: implications for habitat management strategies. Bird Conservation International, 18: 164-80.

Lloyd H., Sevillano Rios S., Marsden S.J. \& ValdesVelasquez A. 2012. Bird community composition across an Andean tree-line ecotone. Austral Ecology, 37(4): 470-478. DOI: 10.1111/j.1442-9993.2011.02308.x.
Lowery G.H. \& Tallman D.A. 1976. A new genus and species of nine-primaried oscine of uncertain affinities from Peru. Auk, 93: 415-428. https://sora.unm.edu/sites/default/files/journals/auk/v093 n03/p0415-p0428.pdf.

Luteyn J. 2002. Diversity, adaptation, and endemism in neotropical Ericaceae: Biogeographical patterns in the Vaccinieae. Botanical Review, 68: 55-87. http://www.jstor.org/stable/4354411.

Mabberley D.J. 1987. The Plant Book: A Portable Dictionary of the Higher Plants. Cambridge University Press: New York.

Maguina R., Amanzo J. \& Huaman L. 2012. Dieta de murciélagos filostómidos del valle de Kosñipata, San Pedro, Cusco - Perú. Revista Peruana de Biología, 19(2): 159-166. DOI: https://doi.org/10.15381/rpb.v19i2.835.

Martin T.E., Nightingale J., Baddams J., Monkhouse J., Kaban A., Sastranegara H., Mulyani Y., Blackburn G.A. \& Simcox W. 2017. Variability in the Effectiveness of Two Ornithological Survey Methods between Tropical Forest Ecosystems. PLoS ONE 12(1): e0169786. DOI: http://doi.org/10.1371/journal.pone.0169786.

Merkord C.L. 2010. Seasonality and elevational migration in an Andean bird community. Ph.D. Dissertation. University of Missouri-Columbia. USA.

Montgomery B., Kelly D. \& Ladley J.J. 2001. Pollinator limitation of seed set in Fuchsia perscandens (Onagraceae) on Banks Peninsula, South Island, New Zealand. New Zealand Journal of Botany, 39(4): 559565. DOI: 10.1080/0028825X.2001.9512759.

Moynihan M. 1963. Inter-specific relations between some Andean birds. Ibis, 105(3): 327-339. DOI: 10.1111/j.1474-919X.1963.tb02511.x.

Muchhala N. \& Jarrin-V. P. 2002. Flower visitation by bats in cloud forests of western Ecuador. Biotropica, 34(3): 387-395. DOI: http://dx.doi.org/10.1646/00063606(2002)034[0387:FVBBIC]2.0.CO;2.

Mutke J., Jacobs R., Meyers K., Henning T. \& Weigend M. 2014. Diversity patterns of selected Andean plant groups correspond to topography and habitat dynamics, not orogeny. Frontiers in Genetics, 5:351. DOI: http://dx.doi.org/10.3389/fgene.2014.00351.

Navarro L., Guitian P. \& Ayensa G. 2008. Pollination ecology of Disterigma stereophyllum (Ericaceae) in south-western Colombia. Plant Biology, 10: 512-518. DOI: 10.1111/j.1438-8677.2008.00059.x.

Nevling N.I. 1971. Ecology of an elfin forest in Puerto Rico. Flowering cycle and an interpretation of its seasonality. Journal of the Arnold Arboretum, 52(4): 1-586.

Ollerton J., Alarcon R., Waser N.M., Price M.V., Watts S., Cranmer L., Hingston A., Peter C.I., \& Rotenberry J. 2009. A global test of the pollination syndrome hypothesis. Annals of Botany, 103(9): 1471-1480. DOI: 10.1093/aob/mcp031.

Parker III T.A \& O’Neill J.P. 1976. Introduction to birdfinding in Peru: Part II. The Carpish Pass region of the eastern Andes along the Central Highway. Birding, 8: 205-216.

Parker III T.A., Stotz D.F. \& Fitzpatrick J.W. 1996. Ecological and distributional databases. In: Stotz D.F., Fitzpatrick J.W., Parker III T.A. \& Moskovits D.K. (eds.). Neotropical birds: ecology and conservation. 113-436. University of Chicago Press, Chicago, Illinois. 
Patterson B.D., Stotz D.F., Fitzpatrick J.W. \& Pacheco V. 1998. Contrasting patterns of elevational zonation for birds and mammals in the Andes of southeastern Peru. Journal of Biogeography, 25(3): 593-607. DOI: 10.1046/j.1365-2699.1998.2530593.x.

Prance G.T. 1989. American tropical forests. In: Lieth, H. \& Werger, M.J.A. (eds.) Tropical Rain Forest Ecosystems. 99-132. Elsevier. Amsterdam.

Puhakka L., Salo M. \& Saaksjarvi I.E. 2011. Bird Diversity, Birdwatching Tourism and Conservation in Peru: A Geographic Analysis. PLoS ONE, 6(11): e26786. DOI:10.1371 /journal. pone.0026786.

Ramirez O., Arana M., Bazan E., Ramirez A. \& Cano A. 2007. Assemblages of two mammal and bird communities in two major ecological units in the high Andean plateau of southern Peru. Ecologia Aplicada, 6(12): 1-15. DOI: http://dx.doi.org/10.21704/rea.v6i1-2.350.

Ramirez-Villegas J., Cuesta F., Devenish C., Peralvo M., Jarvis A. \& Arnillas C.A. 2014. Using species distributions models for designing conservation strategies of Tropical Andean biodiversity under climate change. Journal for Nature Conservation, 22(5): 391-404. DOI: 10.1016/j.jnc.2014.03.007.

Rapp J.M., Silman M.R., Clark J.S., Girardin C.A.J., Galiano D. \& Tito R. 2012. Intra- and interspecific tree growth across a long altitudinal gradient in the Peruvian Andes. Ecology, 93(9): 2061-2072. DOI: 10.1890/11-1725.1.

Remsen J.V., Cadena C.D., Jaramillo A, Nores M., Pacheco J.F., Pérez-Emán J., Robbins M.B., Stiles F.G., Stotz D.F. \& Zimmer K.J. 2016. A classification of the bird species of South America. American Ornithologists' Union. http://www.museum.lsu.edu/ Remsen/SACCBaseline.ht $\underline{\mathrm{m}}$.

Renjifo L.M., Servat G.P., Goerck J.M., Loiselle B.A. \& Blake J.G. 1997. Patterns of species composition and endemism in the northern Neotropics: a case for conservation of montane avifaunas. Ornithological Monographs, 48: 577-594. DOI: $10.2307 / 40157554$.

Renner S.S. 1989a. A survey of reproductive-biology in Neotropical Melastomataceae and Memecylaceae. Annals of the Missouri Botanical Garden, 76: 496-518. DOI: $10.2307 / 2399497$.

Renner S.S. 1989b. Floral biological observations on Heliamphora tatei (Sarraceniaceae) and other plants from Cerro de la Neblina in Venezuela. Plant Systematics and Evolution, 163(1/2): 21-29. http://www.jstor.org/stable/23673955.

Renner S.S. 1998. Effects of habitat fragmentation on plant pollinator interactions in the tropics. In: Newbery, D.M., Prins H.H.T. \& Brown D. (eds.). Dynamics of tropical communities. The 37th Symposium of the British Ecological Society. 339-360. Cambridge University.

Richards P.W. 1996. The Tropical Rainforest. Cambridge. Cambridge University Press.

Robertson A., Kelly D., Ladley J. \& Sparrow A. 1999. Effects of pollinator loss on endemic New Zealand mistletoes (Loranthaceae). Conservation Biology, 13(3): 499-508. DOI: $10.1046 / j .1523-1739.1999 .97471 . x$.

Rodríguez D.A. 2007. Los anuros de los bosques húmedos montanos de Carpish (Huánuco, Perú). Tesis para optar por el título de Biólogo. Universidad Nacional Mayor de San Marcos, Perú. http://cybertesis.unmsm.edu.pe/handle/cybertesis/915.
Rojas-Nossa S.V. 2013. Asociación entre el robo de néctar y las características florales en una comunidad montana de los Andes colombianos. Ecosistemas, 22(2): 107-112. DOI.: 10.7818/ECOS.2013.22-2.16.

Salinas I. 2005. Estudio taxonómico del Orden Scrophulariales (Magnoliopsida) en los bosques húmedos de Carpish (Departamento de Huánuco, Perú). Tesis para optar por el título de Biólogo. Universidad Nacional Mayor de San Marcos, Perú. http://cybertesis.unmsm.edu.pe/handle/cybertesis/1390.

Salinas L., Arana C. \& Suni M. 2007. El néctar de especies de Puya como recurso para picaflores Altoandinos de Ancash, Perú. Revista Peruana de Biologia, 14(1): 129134. http://www.scielo.org.pe/scielo.php?pid=S172799332007000200022\&script=sci arttext.

Schemske D.W. 1983. Limits to specialization and coevolution in plant-animal interactions.. In: Niteki, M.H. (Ed.). Coevolution. 67-109. University of Chicago Press. Chicago.

Schuchmann K.L. 1999. Hummingbirds. In: Del Hoyo J., Elliot A. \& Sargatal J. (eds.). Handbook of the birds of the world. Vol. 5. Barn owls to Hummingbirds. 468-680. Lynx Editions, Barcelona.

Schulenberg T.S., Stotz D.F., Lane D.F., O’Neill J.P. \& Parker III T.A. 2007. Birds of Peru. Princeton Field Guides. Princeton University Press.

Stadtmuller T. 1987. Cloud forest in the humid tropics. A bibliographic review. The United Nations University. Centro Agronómico Tropical de Investigación y Enseñanza. Turrialba, Costa Rica.

Stattersfield A.J., Crosby M.J., Long A.J. \& Wege D.C. 1998. Endemic Bird Areas of the World. BirdLife Conservation Series 7. BirdLife International, Cambridge, UK.

Stiles F.G. 1985. On the role of birds in the dynamics of Neotropical forests. In: Diamond A.W. \& Lovejoy T.E. Conservation of Tropical Forest Birds. 49-59. ICBP Technical Publication 4.

Stiles G., Ayala A. \& Girón M. 1992. Polinizacion de las flores de Brachyotum (Melastomataceae) por dos especies de Diglossa (Emberizidae). Caldasia, 17(1): 4754

Stotz D.F., Fitzpatrick J.W., Parker III T.A. \& Moskovits D.K. 1996. Neotropical Birds: Ecology and Conservation. University of Chicago Press, Chicago.

Sullivan B.L., Aycrigg J.L., Barry J.H., Bonney R.E., Bruns N., Cooper C.B., Damoulas T., Dhondt A.A., Dietterich T., Farnsworth A., Fink D., Fitzpatrick J.W., Fredericks T., Gerbracht J., Gomes C., Hochachka W.M., Iliff M.J., Lagoze C., La Sorte F.A., Merrifield M., Morris W., Phillips T.B., Reynolds M., Rodewald A.D., Rosenberg K.V., Trautmann N.M., Wiggins A., Winkler D.W., Wong W.-K., Wood C.L., Yu J. \& Kelling S. 2014. The eBird enterprise: An integrated approach to development and application of citizen science. Biological Conservation, 169 : 31-40. $\quad$ DOI: 10.1016/i.biocon.2013.11.003.

Sylvester S., Sylvester M.D.P.V. \& Kessler M. 2014. Inaccessible ledges as refuges for the natural vegetation of the high Andes. Journal of Vegetation Science, 25(5): 1-10. DOI: $10.1111 /$ jvs.12176 
Tallman D. 1974. Colonization of a semi-isolated temperate cloud forest: preliminary interpretation of distributional patterns of birds in the Carpish region of the Department of Huánuco, Perú. Master of Science Thesis, Louisiana State University, Baton Rouge, Louisiana.

Tejedor-Garavito N., Álvarez Dávila E., Arango Caro S., Araujo Murakami A., Baldeón S., Beltrán H., Blundo C., Boza Espinoza T.E., Fuentes Claros A. \& Gaviria J. 2014. A regional red list of montane tree species of the tropical Andes: trees at the top of the world. Botanic Gardens Conservation International. Richmond, United Kingdom.

Terborgh J. 1971. Distribution on environmental gradients: Theory and a preliminary interpretation of distributional patterns in the avifauna of the Cordillera Vilcabamba, Peru. Ecology, 52: 23-40. DOI: 10.2307/1934735.

Terborgh J. 1977. Bird species-diversity on an Andean elevational gradient. Ecology, 58(5): 1007-1019. DOI: 10.2307/1936921.

Terborgh J. 1985. The role of ecotones in the distribution of Andean birds. Ecology, 66(4): 1237-1246. DOI: 10.2307/1939177.

Toloza-Moreno D.L., León-Camargo D.A. \& RoseroLasprilla L. 2014. El ciclo anual de una comunidad de colibríes (Trochilidae) en bosques altoandinos intactos y paramizados en la Cordillera Oriental de Colombia. Ornitología Colombiana, 14: 28-47. http://asociacioncolombianadeornitologia.org/wpcontent/uploads/2014/12/MS1011.pdf.

Torres-Mura J.C. \& Hertel F. 2006. Southernmost record of Tennessee Warbler Vermivora peregrine in Chile. Cotinga, 26: 8-9.

Vaicenbacher L., Grim T. \& Greeney H.F. 2014. The nest and eggs of Black-throated flowerpiercer Diglossa brunneiventris. $\quad$ Cotinga, $36:$ 56-57. http://neotropicalbirdclub.org/articles/36/Vaicenbacher.p df.

Valqui T. 2004. Where to watch birds in Peru. Grafica Nañez S.A. Lima-Peru.

Varassin I.G., Penneys D.S. \& Michelangeli F.A. 2008 Comparative Anatomy and Morphology of Nectarproducing Melastomataceae. Annals of Botany, 102(6): 899-909. DOI: $10.1093 / \mathrm{aob} / \mathrm{mcn} 180$.

Vivar S.E. 2006. Análisis de distribución altitudinal de mamíferos pequeños en el Parque Nacional YanachagaChemillen, Pasco, Perú. Tesis para optar por el título de Magister en Zoología con mención en Sistematica y Evolucion. Universidad Nacional Mayor de San Marcos. Facultad de Ciencias Biologicas. Unidad de Postgrado. Lima, Peru. URI http://cybertesis.unmsm.edu.pe/handle/cybertesis/812.
Vuilleumier F. 1970. L'organisation sociale des bandes vagabondes d'oiseaux des Andes du Pérou central [The social organization of vagrant birds in the central Peruvian Andes]. Revue Suisse de Zoologie, 77: 209-235. DOI: http://dx.doi.org/10.5962/bhl.part.75890.

Weberbauer A. 1945. El Mundo Vegetal de los Andes Peruanos. Ministerio de Agricultura, Lima. http://bibdigital.rjb.csic.es/ing/Libro.php?Libro $=48$.

Weberling F. 1989. Morphology of flowers and inflorescences. Cambridge University Press. Cambridge.

Wege D.J. \& Long A.J. 1995. Key areas for threatened birds in the Neotropics. Birdlife Conservation Series No.5. Birdlife International.

Weinstein B.G., Tinoco B., Parra J.L., Brown L.M., McGuire J.A., Gary Stiles F. \& Graham C.H. 2014. Taxonomic, Phylogenetic, and Trait Beta Diversity in South American Hummingbirds. American Naturalist, 184(2): 211-224. DOI: $10.1086 / 676991$.

Willmer P. 2011. Pollination and Floral Ecology. Princeton University Press. USA.

Wolf L.L., Stiles F.G. \& Hainsworth F.R. 1976. Ecological organization of a tropical, highland hummingbird community. Journal of Animal Ecology, 45(2): 349-379. DOI: $10.2307 / 3879$.

Woods S. \& Ramsay P.M. 2001. Variability in nectar supply: implications for high-altitude hummingbirds. In: Ramsay P.M. The ecology of Volcan Chiles: high-altitude ecosystems on the Ecuador-Colombia border. 209-217. Plymouth: Pebble and Shell.

Young B.E. 2007. Endemic species distributions on the east slope of the Andes in Peru and Bolivia. NatureServe. Arlington, Virginia, USA.

Young K.R. \& León B. 2007. Tree-line changes along the Andes: implications of spatial patterns and dynamics. Philosophical Transactions Royal Society B, 362(1478): 263-272. DOI: $10.1098 /$ rstb.2006.1986.

Zimmer J.T. 1930. Birds of the Marshall Field Peruvian Expedition, 1922-1923. Field Museum Natural History, Zoological Series, 17: 233-480. https://www.biodiversitylibrary.org/item/20932\#page/11 Imode/lup.

Zotz G., Mendieta-Leiva G. \& Wagner K. 2014. Vascular epiphytes at the treeline - composition of species assemblages and population biology. Flora, 209: 385390. DOI: $\underline{10.1016 / j . f l o r a .2014 .06 .001}$ 
Table 1. Identity and characteristics of the plants visited by nectarivorous birds at Unchog forest. Frequency in flowers /ha. Very rare $(\mathrm{VR})=$ Less than 40 , Rare $(R)=$ Between $40-100$, Frequent $(F)$ $=$ Between $101-1$ 000, Common $(\mathrm{C})=$ More than 1000 . Life form: $\mathrm{T}=$ tree, $\mathrm{V}=$ vine, $\mathrm{S}=$ Shrub, $\mathrm{H}=$ Herb. Conservation status is based in Leon et al. (2006): $\mathrm{CR}=$ Critical; $\mathrm{EN}=$ Endangered; $\mathrm{VU}=$ Vulnerable; $\mathrm{NE}=$ Not evaluated $; \mathrm{X}=$ endemic without categorization. Pollination syndrome: $\mathrm{O}=$ Ornithophilus, $\mathrm{E}=$ Entomophilus, $\mathrm{C}=$ Chiropterophilus.

\begin{tabular}{|c|c|c|c|c|}
\hline Taxa & Frequency & $\begin{array}{c}\text { Life } \\
\text { form }\end{array}$ & $\begin{array}{c}\text { Conservation } \\
\text { Status } \\
\end{array}$ & $\begin{array}{c}\text { Pollination } \\
\text { syndrome }\end{array}$ \\
\hline \multicolumn{5}{|l|}{ ASTERALES } \\
\hline \multicolumn{5}{|l|}{ Campanulaceae } \\
\hline $\begin{array}{l}\text { Centropogon isabellinus } \mathrm{E} \text {. Wimm } \\
\text { BRASSICALES }\end{array}$ & $\mathrm{F}$ & $S$ & $\mathrm{X}$ & $\mathrm{O}$ \\
\hline \multicolumn{5}{|l|}{ Tropaeolaceae } \\
\hline $\begin{array}{l}\text { Tropaeolum bicolor Ruiz \& Pav. } \\
\text { ERICALES }\end{array}$ & VR & V & & $\mathrm{O}$ \\
\hline \multicolumn{5}{|l|}{ Ericaceae } \\
\hline Disterigma spp.* & $\mathrm{F}$ & $S$ & & $\mathrm{E}$ \\
\hline Gaultheria bracteata G. Don & $\mathrm{C}$ & S & & \\
\hline $\begin{array}{l}\text { Pellegrinia hirsuta (Ruiz \& Pav. Ex G. Don) } \\
\text { Sleumer }\end{array}$ & VR & $S$ & $\mathrm{NE}$ & $\mathrm{O}$ \\
\hline Vaccinium floribundum H.B.K. & $\mathrm{C}$ & $\mathrm{H}$ & & $\mathrm{E}$ \\
\hline \multicolumn{5}{|l|}{ FABALES } \\
\hline \multicolumn{5}{|l|}{ Polygalaceae } \\
\hline \multicolumn{5}{|l|}{ GENTIANALES } \\
\hline \multicolumn{5}{|l|}{ Gentianaceae } \\
\hline $\begin{array}{l}\text { Gentianella fruticulosa (Dombey ex Weddell) } \\
\text { Fabris ex J. Pringle }\end{array}$ & $\mathrm{C}$ & $\mathrm{H}$ & EN & $\mathrm{O}$ \\
\hline \multicolumn{5}{|l|}{ GENTIANALES } \\
\hline \multicolumn{5}{|l|}{ Loganiaceae } \\
\hline \multicolumn{5}{|l|}{ LILIALES } \\
\hline \multicolumn{5}{|l|}{ Alstroemeriaceae } \\
\hline Bomarea brevis (Herb.) Baker & $\mathrm{C}$ & $\mathrm{H}$ & & $\mathrm{O}$ \\
\hline \multicolumn{5}{|l|}{ MYRTALES } \\
\hline \multicolumn{5}{|l|}{ Melastomataceae } \\
\hline Brachyotum lutescens (Ruiz \& Pav.) Triana & $\mathrm{C}$ & $S$ & $\mathrm{CR}$ & $\mathrm{O}$ \\
\hline Brachyotum naudinii Triana & $\mathrm{C}$ & $S$ & & $\mathrm{O}$ \\
\hline Meriania radula (Benth.) Triana, 1872 & VR & $\mathrm{T}$ & & $\mathrm{E}$ \\
\hline Miconia alpina Cogn. & VR & $\mathrm{T}$ & $\mathrm{X}$ & $\mathrm{E}$ \\
\hline \multicolumn{5}{|l|}{ MYRTALES } \\
\hline \multicolumn{5}{|l|}{ Onagraceae } \\
\hline $\begin{array}{l}\text { Fuchsia decussata Ruiz \& Pav. } \\
\text { POALES }\end{array}$ & $\mathrm{C}$ & $\mathrm{V}$ & & $\mathrm{O}$ \\
\hline \multicolumn{5}{|l|}{ Bromeliaceae } \\
\hline Greigia macbrideana L.B. Sm. & VR & $\mathrm{H}$ & EN & $\mathrm{E}$ \\
\hline Puya pseudoeryngioides $\mathrm{H}$. Luther & $\mathrm{C}$ & $\mathrm{H}$ & $\mathrm{CR}$ & $\mathrm{O}$ \\
\hline \multicolumn{5}{|l|}{ RANUNCUNALES } \\
\hline \multicolumn{5}{|l|}{ Berberidaceae } \\
\hline \multicolumn{5}{|l|}{ ROSALES } \\
\hline \multicolumn{5}{|l|}{ Rosaceae } \\
\hline Rubus sp.** & $\mathrm{C}$ & S & & $\mathrm{C}$ \\
\hline SANTALALES & & & & \\
\hline Loranthaceae & & & & \\
\hline Gaiadendron punctatum G. Don. & VR & $S$ & & $\mathrm{E}$ \\
\hline $\begin{array}{l}\text { Tristerix longebracteatus (Desr.) Barlow \& Wiens } \\
\text { SAXIFRAGALES }\end{array}$ & $\mathrm{C}$ & $S$ & & $\mathrm{O}$ \\
\hline Grossulariaceae & & & & \\
\hline $\begin{array}{l}\text { Ribes incarnatum Wedd. } \\
\text { SOLANALES }\end{array}$ & $\mathrm{R}$ & V & & $\mathrm{E}$ \\
\hline Solanaceae & & & & \\
\hline
\end{tabular}


Table 1. Identity and characteristics of the plants visited by nectarivorous birds at Unchog forest. Frequency in flowers /ha. Very rare $(\mathrm{VR})=$ Less than 40 , Rare $(\mathrm{R})=$ Between $40-100$, Frequent $(\mathrm{F})$ $=$ Between $101-1000$, Common $(\mathrm{C})=$ More than 1 000. Life form: $\mathrm{T}=$ tree, $\mathrm{V}=$ vine, $\mathrm{S}=\mathrm{Shrub}$, $\mathrm{H}=$ Herb. Conservation status is based in Leon et al. (2006): CR = Critical; $\mathrm{EN}=$ Endangered; $\mathrm{VU}=$ Vulnerable; $\mathrm{NE}=$ Not evaluated $\mathrm{X}=$ endemic without categorization. Pollination syndrome: $\mathrm{O}=$ Ornithophilus, $\mathrm{E}=$ Entomophilus, $\mathrm{C}=$ Chiropterophilus.

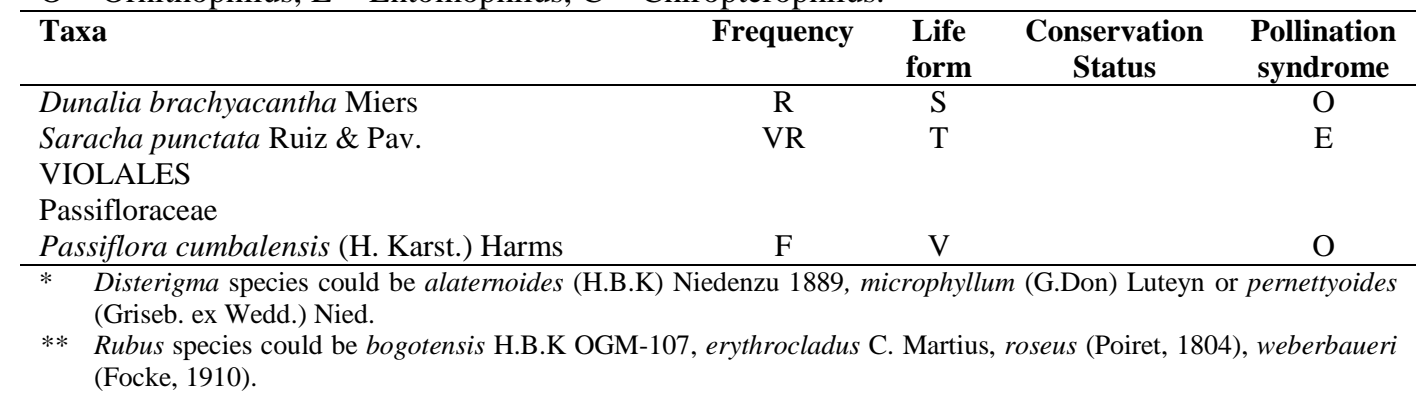

Table 2. Identity and characteristics of the nectarivorous bird assemblage. The frequency criteria is based on data of individuals captured in 100 net-hours: No data (ND), Very rare (VR) $=$ Less than 2, Rare $(\mathrm{R})=$ Between 3 to 5, Frequent $(\mathrm{F})=$ Between 6 to 11 , Common $(\mathrm{C})=$ more than 12 . Conservation status: $\mathrm{E}=$ Endemic for Peru, I= Elfin forest indicators (Parker et al. (1996). Record: $\mathrm{x}$ = This study, e = eBird.

\begin{tabular}{|c|c|c|c|}
\hline Taxa & Frequency & $\begin{array}{c}\text { Conservation } \\
\text { status } \\
\end{array}$ & Record \\
\hline \multicolumn{4}{|l|}{ APODIFORMES } \\
\hline \multicolumn{4}{|l|}{ Trochilidae } \\
\hline Colibri thalassinus (Swainson, 1827) & ND & & $\mathrm{e}$ \\
\hline Colibri coruscans (Gould, 1846) & ND & & $\mathrm{e}$ \\
\hline Heliangelus amethysticollis (d'Orbigny \& Lafresnaye 1838) & $\mathrm{R}$ & & $\mathrm{x}, \mathrm{e}$ \\
\hline Lesbia victoriae (Bourcier \& Mulsant, 1846) & VR & & $\mathrm{x}, \mathrm{e}$ \\
\hline Ramphomicron microrhynchum (Boissonneau, 1840) & VR & & $\mathrm{x}$ \\
\hline Chalcostigma ruficeps (Gould, 1846) & ND & & $\mathrm{e}$ \\
\hline Chalcostigma stanleyi (Bourcier, 1851) & ND & & $\mathrm{e}$ \\
\hline Metallura tyrianthina (Loddiges, 1832) & $\mathrm{R}$ & & $\mathrm{x}, \mathrm{e}$ \\
\hline Metallura theresiae (Simon, 1902) & $\mathrm{C}$ & $\mathrm{E}, \mathrm{I}$ & $\mathrm{x}, \mathrm{e}$ \\
\hline Metallura phoebe (Lesson \& Delattre, 1839) & ND & & $\mathrm{e}$ \\
\hline Aglaeactis cupripennis (Bourcier 1843) & VR & & $\mathrm{x}, \mathrm{e}$ \\
\hline Aglaeactis castelnaudii (Bourcier \& Mulsant, 1848) & ND & & $\mathrm{e}$ \\
\hline Coeligena torquata (Boissonneau 1840) & VR & & \\
\hline Coeligena violifer (Gould, 1846) & $\mathrm{F}$ & & $\mathrm{x}, \mathrm{e}$ \\
\hline Lafresnaya lafresnayi (Boussonneau 1840) & VR & & $\mathrm{x}, \mathrm{e}$ \\
\hline Ensifera ensifera (Boissonneau 1840) & $\mathrm{R}$ & & $\mathrm{x}, \mathrm{e}$ \\
\hline Pterophanes cyanopterus (Fraser, 1840) & $\mathrm{F}$ & $\mathrm{I}$ & $\mathrm{x}, \mathrm{e}$ \\
\hline Patagona gigas (Vieillot, 1824) & $\mathrm{R}$ & & $\mathrm{x}, \mathrm{e}$ \\
\hline Amazilia chionogaster (von Tschudi, 1846) & ND & & $\mathrm{e}$ \\
\hline \multicolumn{4}{|l|}{ PASSERIFORMES } \\
\hline \multicolumn{4}{|l|}{ Thraupidae } \\
\hline Conirostrum cinereum (d'Orbigny \& Lafresnaye 1838) & ND & & $\mathrm{e}$ \\
\hline Conirostrum sitticolor (Lafresnaye, 1840) & ND & & $\mathrm{e}$ \\
\hline Conirostrum ferrugineiventre (Sclater, PL, 1855) & VR & I & $\mathrm{x}, \mathrm{e}$ \\
\hline Diglossa mystacalis (Lafresnaye, 1846) & $\mathrm{C}$ & & $\mathrm{x}, \mathrm{e}$ \\
\hline Diglossa brunneiventris (Lafresnaye, 1846) & $\mathrm{C}$ & & $\mathrm{x}, \mathrm{e}$ \\
\hline Diglossa sittoides (d'Orbigny \& Lafresnaye 1838) & VR & & $\mathrm{x}, \mathrm{e}$ \\
\hline Diglossa cyanea (Lafresnaye 1840) & VR & & $\mathrm{x}, \mathrm{e}$ \\
\hline
\end{tabular}


${ }^{1}$ Department of Wildlife Ecology, University of Florida, Gainesville, FL 32611-0430, USA.; Department of Natural Sciences, Emmanuel College, Franklin Springs, GA 30639, USA; Grupo Aves del Perú. Gómez del Carpio 135, Lima 34, Perú. Corresponding author: e-mail: ogonzalez@ec.edu.

${ }^{2}$ Laboratorio de Botánica Aplicada. Facultad de Ciencias y Filosofía. Universidad Peruana Cayetano Heredia. Av. Honorio Delgado 430, San Martin de Porres, Lima, Perú.

${ }^{3}$ División Ecología. Museo de Historia Natural. Universidad Nacional Mayor de San Marcos. Av. Arenales 1256, Jesús María, Lima, Perú. 